R. E. Byrd, U.S.N. The vehicle, called the Snow Cruiser, is to be used as a mobile base, and it is reported to be capable of travelling across ice fields, of climbing gradients of 35 per cent, of sliding down them on its steel-ribbed under-floor and of erossing crevasses in the ice $15 \mathrm{ft}$. wide. The Snow Cruiser is more than $55 \mathrm{ft}$. long, $20 \mathrm{ft}$. wide and $15 \mathrm{ft}$. high, and weighs, fully equipped, $33 \frac{1}{2}$ tons. It has four pneumatic-tyred wheels $10 \mathrm{ft}$. in diameter which can be turned independently to various angles, and which can also be retracted into the vehicle. The structure is of steel electrically welded, and the motive power consists of two 150 h.p. oil engines driving electric generators supplying current to the traction motors. In the interior are the living quarters, store-rooms, the engine room, a machine shop and a laboratory, and also tanks for the storage of 2,100 gallons of oil fuel and of nearly 850 gallons of petrol for the aeroplane carried on the back of the vehicle. The Snow Cruiser was designed and constructed by the Research Foundation of Armour Institute in Chicago, under the direction of Dr. T. C. Poulter, scientific director of the Foundation, who was second-in-command of the second Byrd expedition.

\section{Puffin Crosses North Atlantic}

ONE of the most important results of bird-ringing experiments is the first recovery in North America of a puffin (Fratercula arctica arctica) ringed in Europe. This was a specimen ringed by Lord Dumfries as a young bird on St. Kilda on August 10, 1939, and shot at Herring Neck on the north coast of Newfoundland on December 20, 1939 (British Birds, March 1940). The instances of European-marked birds traced to North America are very few. The most numerous records are of the kittiwake (Rissa tridactyla); specimens marked as young on the Farne Islands, Northumberland, have been recovered in autumn and winter months at Davis Strait, Labrador, and Newfoundland over periods since 1924; another specimen ringed at Khasilov Island, in the Barents Sea, was recovered at Little Fogs Island, Newfoundland. Black-headed gulls (Larus ridibundus) ringed at Rossitten, East Prussia, have been recovered in Mexico and the Barbadoes, and there is the celebrated record of Cumberland lapwings (Vanellus vanellus) shot in Newfoundland after a gale forced them from their normal migration to Ireland. Previous ringing returns of Scottish puffins have shown no marked westerly migration. Specimens from Northumberland have been recovered at Norway.

\section{Effect of Winter Frosts on Bird-life}

IN a lecture to the Hastings and St. Leonards Natural History Society on April 23, Mr. Eric Hardy described the serious effect upon the numbers of insectivorous British birds as a result of the severe frosts during the past winter, when, particularly in the north, vast numbers of thrushes, blackbirds, titmice and other birds were killed by the long absence of food and water. In recounting at length many of his ornithological studies in the north, Mr. Hardy stressed the possible effect of this partial loss of useful insectivorous birds at a time of national food-growing efforts, and the possibilities of increased wireworm damage to cornland, and cabbage white caterpillars to cultivated greens. There is a marked shortage of many of the residential insect-eating birds in woods in the north, although Nature has recovered from the severe winter toll of bird-life more rapidly than was anticipated and it will be interesting to compare the future results with previous hard winters. "Nevertheless, there is an urgent need to protect and increase insectivorous birds by providing more nesting and feeding haunts, for example, growing more undergrowth in woods and plantations, and preventing loss of existing bird haunts by river pollution and heath fires.

\section{Canada's Indian Policy}

$A_{N}$ interesting review of the circumstances and problems of the Indian population of Canada was given by Mr. Diamond Jenness of the National Museum of Canada, at the recent meeting of the American Association for the Advancement of Science at Columbus, Ohio. The Indian policy of the Canadian Government was framed at a time when to civilize in accordance with the white man's ideals, rather than to conserve, was the aim of liberal and humanitarian administration. Further, it was considered inevitable that such backward peoples would be unable to withstand the difficulties and dangers of contact with civilization and must become extinct. Hence Canadian policy was fusion of the two populations rather than segregation. The Indian was gradually to be absorbed by the white.

Of recent years, however, in Canada, as in other parts of America, the Indian population is increasing ; but a more or less successful adaptation to changed conditions, if it has not actually contributed to the increase, as is probable, has certainly averted untoward consequences. This is implied in the comment by Mr. Jenness that the Iroquoians of eastern Canada, "being an agricultural people, ... . were not forced to undergo any sudden revolution". Among the Plains Indians, in the difficult transition from buffalo hunting to growing wheat, the Blackfoot, now the most prosperous, had the advantage of being guided by able and far-sighted chiefs. The Indians of the Pacific coast, both in temperament and economy, have proved less capable of readjustment; but in the Arctic, as might be expected, the Eskimo show themselves well able to hold their own, while the women make excellent wives for the white pioneers who settle on this frontier.

\section{Bureau of American Ethnology, r938-39}

THE major field research with which the Bureau of American Ethnology was associated in the fiscal year 1938-39 (Fifty-sixth Annual Report, 1938-1939, 1940) continued to be that of the United States De Soto Expedition Commission. For the greater part of the year Dr. John R. Swanton was in the field in the interests of the Commission or engaged in the preparation of its report. With various members of the Commission he visited points in North 
and South Carolina, Georgia, Florida, Missouri, Mississippi, Arkansas and Louisiana. The report has since appeared in a volume of 400 pages.

A joint expedition of the Bureau and the National Geographic Society, under M. W. Stirling, chief of the Bureau, carried out an excavation on a mound site at Tres Zapotes, Vera Cruz, Mexico. Nine major stone monuments were excavated and a large collection of ceramics and figurines obtained. The most important find was a Mayan stone monument inscribed with an initial-series date which apparently records a late Baktan 7 date and is thus among the earliest at present known. The style is closely related to the Tuxtla statuette. This important document has now been deposited in the National Museum, Mexico City. Among other researches, special interest attaches to the investigation of the northern provenience of the Navajo, the largest single-dialect Indian population in the United States, numbering some 50,000 souls, inhabiting Arizona and New Mexico. Their language is an aberrant form of Western Apache, belonging to a group of which the northern origin is patent and traceable as closely related to Athapascan tongues occupying the interior of Alaska and western Canada. Dr. F. H. H. Roberts, continuing his researches on the character and distribution of Folsom man in the period under review, has traced this early prehistoric culture so far north as Saskatchewan, along the postulated migration route of peoples coming from Asia into the New World.

\section{Canadian Polar Year Expeditions, r932-33}

THE Second International Polar Year, 1932-33, during which many nations joined in the simultaneous recording of meteorological, geomagnetic and auroral data in the polar and other regions of the globe, belonged to an epoch when the nations of Europe and elsewhere could still devote money and energy to a great co-opèrative scientific enterprise. Though receding in memory, some of its fruits still remain ungarnered; this has now been accomplished, for the share of Canada in the magnetic and auroral part of that enterprise, by the publication of volume 2 of the report of the three Canadian expeditions (volume 1 deals with the meteorological results). A now magnetic observatory was set up for the year at Chesterfield Inlet $\left(63 \cdot 3^{\circ} \mathrm{N}\right.$., $90 \cdot 7^{\circ} \mathrm{W}$.), which is not far from the north magnetic pole- the magnetic needle at Chesterfield Inlet departs from the vertical by only $3 \cdot 6^{\circ}$-and is also near the auroral zone, the centre of which is the pole of the earth's magnetic axis. In addition, the equipment of the Meanook Observatory, set up in 1916, was improved for the Polar Year work : Meanook (54.6 $6^{\circ}$ N., $113 \cdot 3^{\circ}$ W.) is also in a high magnetic latitude.

The report gives very full details, on an internationally arranged plan, of the magnetic observations made during the year at these two stations; the tables cover more than eighty quarto pages closely printed; they are likely to prove, for many years, valuable raw material for theoretical studies, as was the case with the records of the first Polar Year (1882-83), the value of which is still not exhausted.
In addition, the report gives particulars of earth eurrent observations at Chesterfield Inlet, and of magnetic measurements at field stations visited from Chesterfield; together with more than fifty pages of records and discussion of auroral observations made at Saskatoon and at Chesterfield Inlet; this part of the report is illustrated by many line diagrams and photographs of auroras. Height measurements were made by simultaneous photography from two stations separated by $112 \mathrm{~km}$.; they showed that the most usual height of the lower edge of the auroras measured was about $100 \mathrm{~km}$., as in Norway. Auroras extending below $80 \mathrm{~km}$. were observed on at least one occasion.

\section{Robert Mond Bequest to the British Museum}

A FURTHER instalment of descriptive notes on outstanding objects in the collection of antiquities bequeathed to the British Museum by the late Sir Robert Mond (Brit. Mus. Quarterly, 14, 1 ; 1940) deals with funerary portraits of the Roman period from the Fayyum, an example of a theriomorphic vase possibly of the middle predynastic period in the form of a frog and two small granite heads, of which the smaller presents the remarkable and unusual feature that the eyes are shut, so that the effect is that of the portrait of a dead person, while the contour of the main features resembles that of a skeleton. It seems to be without parallel, and no opinion can be expressed as to its age without the greatest reserve. Much interest is attached to a small hollow cylinder of black and white porphyritic rock, which belongs to a class of objects of which the use has not yet been determined satisfactorily. At one time they were thought to be mace heads, though secure hafting seems an impossibility; but recent discoveries at Wadi Halfa, in which they were found in association with other weapons and in some burials with two fingers of the right hand, have led to the suggestion that they were archers' looses, and in their use resembled the Mongolian ring. All datable examples are from sites occupied by the people to whom archæologists apply the term the $X$-group, who occupied Upper and Lower Nubia from the third to the sixth centuries A.D., variously identified with the Blemmyer of the Eastern Desert, the Noubades, a mixed race of negroid and Meroitic elements, and the Nobatae, who are alleged by Procopius to have formed a buffer State between the Roman frontier at the First Cataract and the southern barbarian tribes.

\section{Taxonomy in the Amaryllidaceæ}

THE present trend towards specialization makes possible, and indeed necessary, a detailed volume such as Herbertia, the year-book of the American Amaryllis Society. The editor, Dr. Hamilton P. Traub, has brought together in the sixth book, for 1939, a collection of knowledge upon all matters pertaining to the horticulturally valuable members of the Amaryllidaceæ. There are the usual descriptions of exhibitions and garden culture, of grouping and floral artistry; there is. a dedication of the present volume to the Union of South Africa; there are 